\title{
BIOSPELEOLOŠKA ISTRAŽIVANJA ŠPILJA I JAMA NACIONALNOG PARKA SJEVERNI VELEBIT U 2018. GODINI
}

Petra Bregović

Tin Rožman

Jana Bedek

Tvrtko Dražina

Branko Jalžić

Ana Komerički

Marko Lukić

Martina Pavlek

Hrvatsko biospeleološko društvo

Demetrova 1

HR 10000 Zagreb

bregovicpetra@gmail.com

rozman.tin@gmail.com

jana.bedek@hbsd.hr

tdrazina@gmail.com

jalzicbranko@gmail.com

ana.komericki@hbsd.hr

marko.lukic@hbsd.hr

martina.pavlek@gmail.com
UDK: 55:51(234Velebit)

Izvorni znanstveni članak

19.09.2019.

Projektom Biospeleološka istraživanja i inventarizacija faune u speleološkim objektima Nacionalnog parka Sjeverni Velebit u suradnji Javne ustanove "Nacionalni park Sjeverni Velebit" i Hrvatskog biospeleološkog društva, biospeleološki je istraženo 5 speleoloških objekata: Jama pod Budinom kosicom, Jama u kuku, Sniježnica u Medvjeđoj dolini, Špilja u Štirovači i Terca. U svakom je objektu sakupljana fauna, mjereni su mikroklimatski parametri te su fotodokumentirani ulaz, unutrašnjost objekta i fauna. Detaljno su taksonomski obrađene skupine pauka (Araneae), jednakonožnih rakova (Isopoda), striga (Chilopoda), dvojenoga (Diplopoda), skokuna (Collembola) i kornjaša (Coleoptera). Rezultati ovog istraživanja značajno su doprinijeli poznavanju podzemne faune Parka te su naglasili važnost i potrebu sustavne inventarizacije podzemne faune speleoloških objekata.

Ključne riječi: biospeleologija, Dinaridi, podzemna fauna, endemi, speleološki objekti 


\section{Uvod}

U 2018. godini pokrenut je projekt Biospeleološka istraživanja $i$ inventarizacija faune u speleološkim objektima Nacionalnog parka Sjeverni Velebit u suradnji Javne ustanove "Nacionalni park Sjeverni Velebit" (u daljnjem tekstu: Park) i Hrvatskog biospeleološkog društva (u daljnjem tekstu: HBSD).

Rezultati dosadašnjih faunističkih i speleoloških istraživanja Parka poslužili su kao osnova za izradu plana istraživanja i odabir speleoloških objekata koji dosad nisu bili sustavno biospeleološki istraživani. Ukupno je odabrano pet speleoloških objekata za koje je pretpostavljeno da zbog svoje morfologije, položaja i nadmorske visine sadrže raznolika staništa i potencijalno različite vrste (Tabl. 1, Sl.1).

Objekti su istraživani u razdoblju od 28. kolovoza 2018. do 2. rujna 2018., uz dva pripremna terenska izlaska u razdoblju od 20. srpnja 2017. do 21. srpnja 2017 i 31. srpnja 2018.

Tabl. 1. Popis speleoloških objekata istraženih 2018. godine s pridruženim geografskim koordinatama u HTRS96 sustavu i katastarskim brojem. ${ }^{1}$

\begin{tabular}{|c|c|c|c|c|c|}
\hline \multirow{2}{*}{$\begin{array}{c}\text { Redni } \\
\text { broj }\end{array}$} & Ime objekta & Lokalitet & \multicolumn{2}{|c|}{ HTRS96 koordinate } & Katastarski \\
\cline { 4 - 6 } & & & $\mathrm{X}$ & $\mathrm{Y}$ & broj \\
\hline 1. & $\begin{array}{c}\text { Jama pod Budinom } \\
\text { kosicom }\end{array}$ & Zavižanska Kosa & 378720.97 & 4964711.38 & - \\
\hline 2. & Jama u kuku & Babrovača & 376657.76 & 4965334.7 & - \\
\hline 3. & Terca & Golubić & 384680.59 & 4959002.44 & HR00499 \\
\hline 4. & Špilja u Štirovači & Štirovača & 385481.59 & 4951884.35 & HR01272 \\
\hline 5. & $\begin{array}{c}\text { Sniježnica u Medvjeđoj } \\
\text { dolini }\end{array}$ & Veliki Zavižan & 379007.94 & 4963729.74 & - \\
\hline
\end{tabular}

\section{Materijali i metode}

Terenski rad proveden je pomoću standardne speleološke opreme, a za savladavanje vertikalnih dijelova speleoloških objekta korištene su speleološke SRT (engl. single rope technique) tehnike.

U objektima su mjereni mikroklimatski parametri, točnije temperatura zraka i sedimenta i relativna vlažnost zraka. Mjerenja su izvršena ubodnim termometrom Mini Thermometer tvrtke TESTO, termohigro-anemometrom

${ }^{1}$ MINISTARSTVO ZAŠTITE OKOLIŠA I ENERGETIKE, Informacijski sustav zaštite prirode - Katastar speleoloških objekata Republike Hrvatske, Zagreb, 2019, URL: http:// natura2000.dzzp.hr/speleo/ (2019-11-29) 


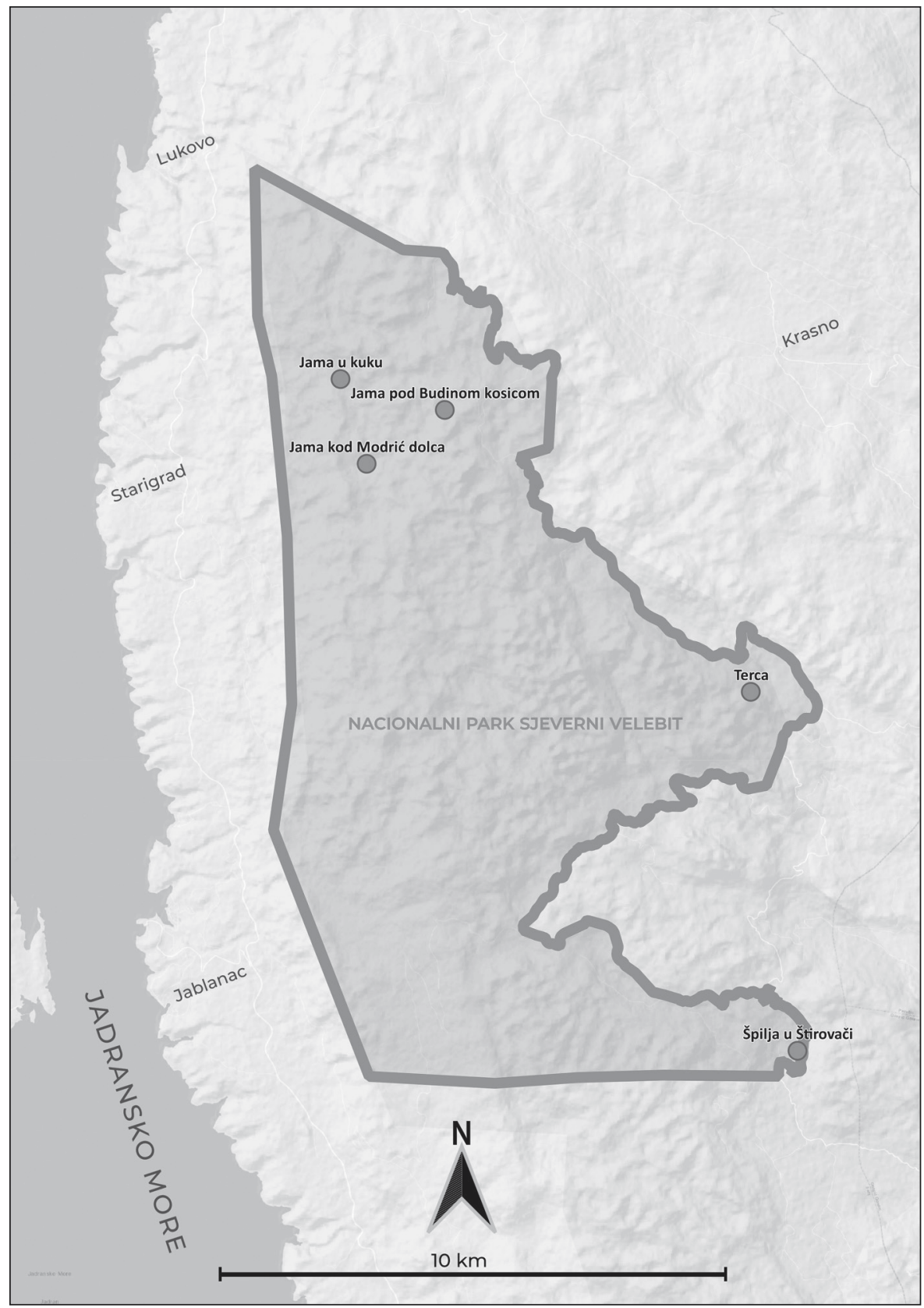

S1. 1. Karta s označenim speleološkim objektima iz Tablice 1. (autor: Tin Rožman) 


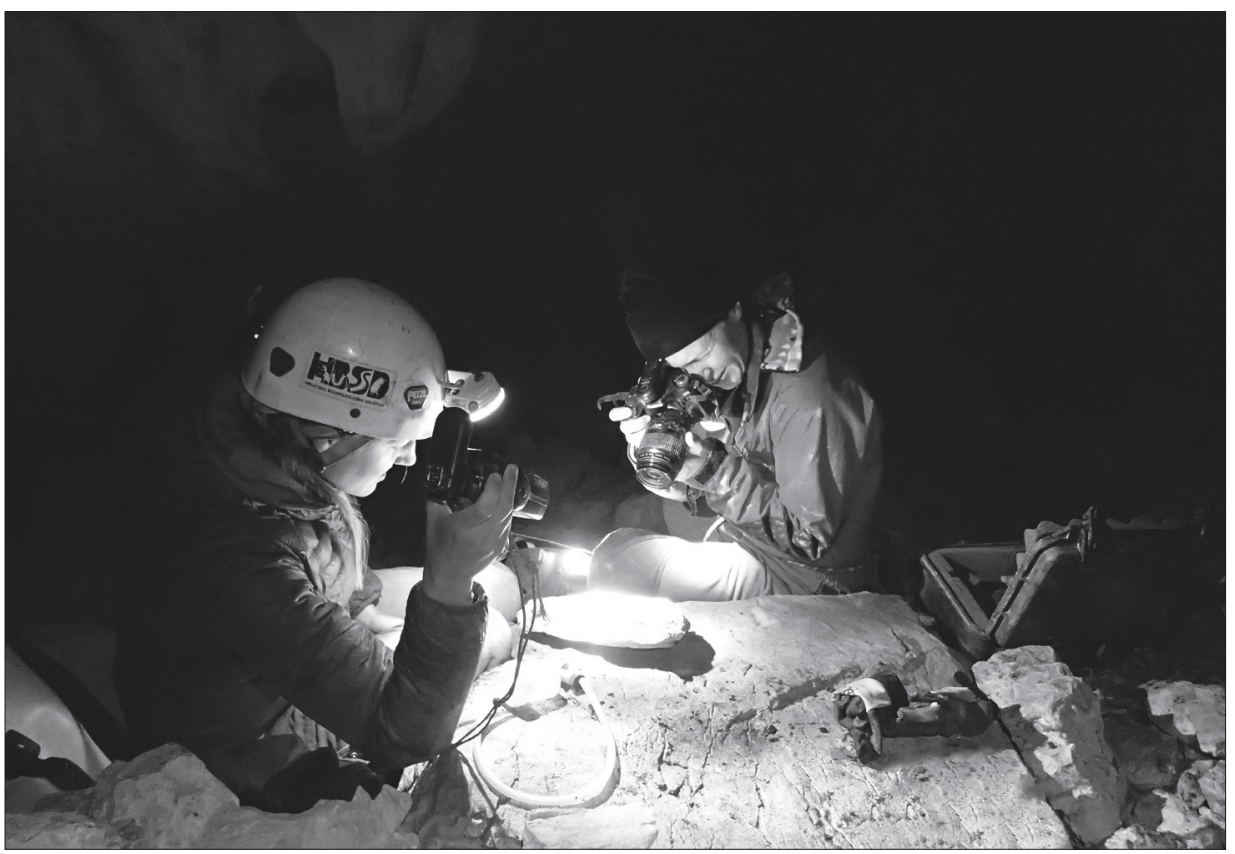

Sl. 2. Fotografiranje podzemne faune u Špilji u Štirovači (foto: Anđela Ćukušić)

Kestrel 3000 tvrtke Nielsen Kellerman i termohigrometrom 810-155 tvrtke Electronic Temperature Instruments Ltd.

Fotodokumentiran je ulaz istraživanih speleoloških objekata, unutrašnjost objekta, istraživanje i fauna (S1. 2.). Unutrašnjost speleoloških objekata i fauna fotografirani su digitalnim SLR fotoaparatom Canon EOS 80D uz upotrebu objektiva Canon MP-E 65mm f/2.8, Canon EF 100 mm f/2.8 i Canon EF-S 10$22 \mathrm{~mm} \mathrm{f} / 3.5$. Za osvjetljenje su korištene dvije Canon bljeskalice 430 EX II. Osim toga, korišten je još Olympus SP-800UZ za fotografiranje ulaza u speleološke objekte i Olympus TG-3.

Biološki materijal u dostupnim špiljskim staništima sakupljan je ručnim tehnikama - pincetama i ekshaustorima (S1. 3.). Sakupljena fauna pohranjena je u 40\% etanol, 70\% etanol, 75\% etanol s glicerolom ili 96\% etanol, ovisno o taksonomskoj skupini. Nakon sakupljanja, fauna je etiketirana, a materijal je pohranjen u zbirku HBSD-a. Na etiketi je zabilježen točan lokalitet, datum, sakupljač (legator), postotak etanola i što točnija determinacija. Determinacija je provođena korištenjem relevantne literature i komparativnog materijala iz zbirke HBSD-a. Za potrebe izolacije i određivanja biološkog materijala korištene su 


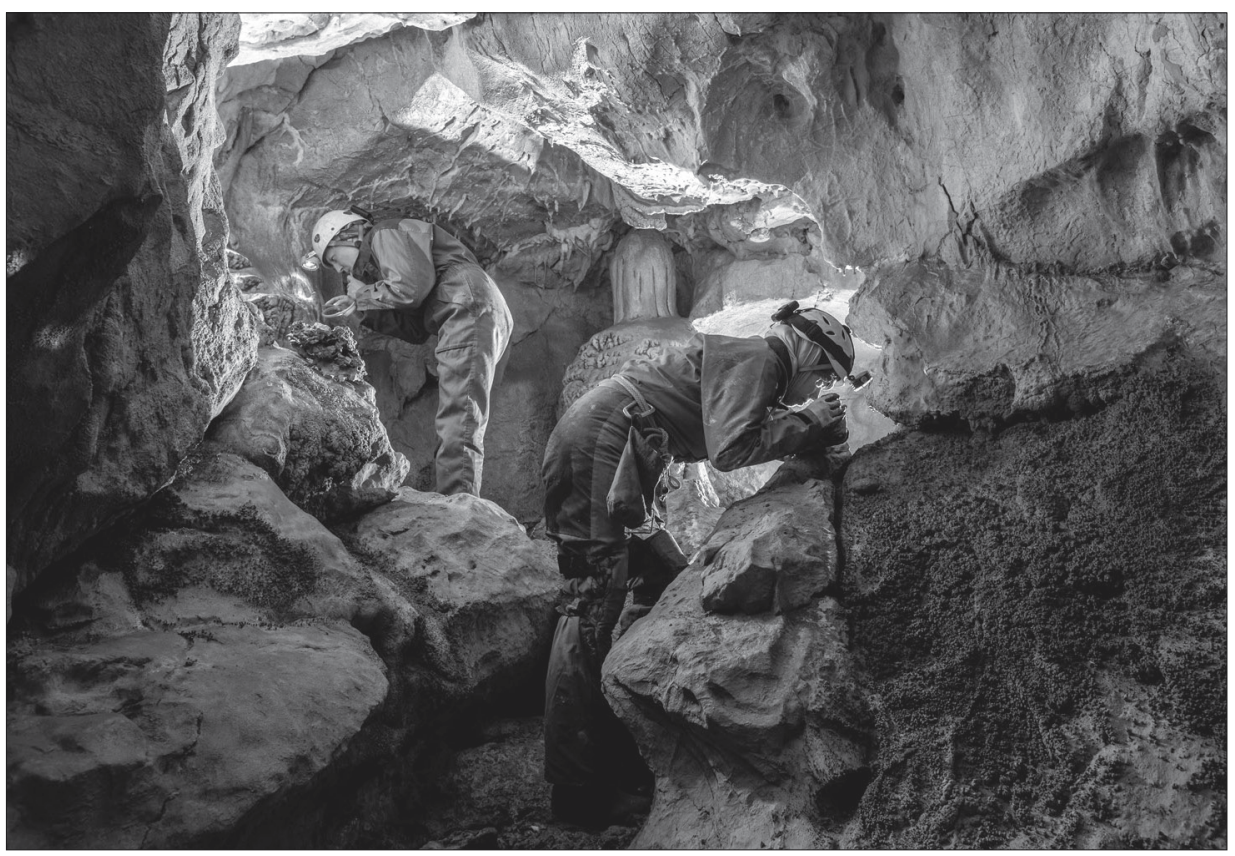

Sl. 3. Sakupljanje faune u Špilji u Štirovači (foto: Tin Rožman)

binokularne lupe Carl Zeiss Stemi 2000-C i XTL-2400 D te mikroskop sa faznim kontrastom Zeiss Primostar i Nikon Labophot.

Geografske koordinate ulaza u speleološke objekte određivane su GPS uređajem Garmin eTrex 30x.

\section{Rezultati}

\section{Mikroklimatska obilježja speleoloških objekata i podzemnih staništa}

Mikroklimatska mjerenja uključila su izmjere temperature zraka, sedimenta i relativne vlažnosti (Tabl. 2). Mjerenja su obavljena u svakom od pet objekata, a u većim objektima i na dvije lokacije unutar objekta. Raspon izmjerenih temperatura zraka $\mathrm{u}$ istraživanim objektima se kreće od $2,9^{\circ} \mathrm{C}$ izmjerenih u dubljem dijelu jame Terca pa sve do $9,8^{\circ} \mathrm{C}$ izmjerenih u gornjem, špiljskom dijelu Sniježnice u Medvjeđoj dolini. Jedino veće odstupanje $\left(1,4^{\circ} \mathrm{C}\right)$ između temperature zraka i sedimenta na istom lokalitetu, unutar objekta, je zabilježeno u Sniježnici u Medvjeđoj dolini. Taj rezultat pokazuje da je, zbog specifične morfologije objekta, temperatura zraka podložna vanjskim 
utjecajima, a da je prosječna temperatura objekta bliža temperaturi sedimenta $\left(8,4^{\circ} \mathrm{C}\right)$. Najveća razlika u temperaturi unutar istog objekta zabilježena je u jami Terca gdje je u dvorani na $30 \mathrm{~m}$ dubine zabilježena temperatura zraka od $7,4^{\circ} \mathrm{C}$, dok je u dvorani na $50 \mathrm{~m}$ dubine izmjereno $2,9^{\circ} \mathrm{C}$ što čini značajnu razliku od $4,5^{\circ} \mathrm{C}$. Dublji dijelovi ove jame nisu obuhvaćeni ovim istraživanjem zbog potencijalne opasnosti od većih količina leda koje se nakupljaju u meandru. ${ }^{2}$

Tabl. 2. Rezultati mikroklimatskih mjerenja u objektima istraženim 2018. godine.

\begin{tabular}{|c|c|c|c|c|c|c|}
\hline $\begin{array}{c}\text { Redni } \\
\text { broj }\end{array}$ & Naziv objekta & Datum & Mikrolokalitet & $\begin{array}{c}\text { Tzrak } \\
\left({ }^{\circ} \mathrm{C}\right)\end{array}$ & $\begin{array}{l}\text { Tsediment } \\
\left({ }^{\circ} \mathrm{C}\right)\end{array}$ & $\begin{array}{c}\text { Relativna } \\
\text { vlažnost } \\
(\%)\end{array}$ \\
\hline 1. & $\begin{array}{l}\text { Jama pod } \\
\text { Budinom } \\
\text { kosicom }\end{array}$ & 29. 8. 2018. & Dno & 5.1 & 4.9 & 86 \\
\hline \multirow{2}{*}{2.} & \multirow{2}{*}{ Jama u kuku } & \multirow{2}{*}{ 30. 8. 2018.} & 1. polica & 8.9 & 8.5 & 64 \\
\hline & & & 2. polica & 7.2 & 6.9 & 84 \\
\hline \multirow{2}{*}{3.} & \multirow{2}{*}{ Terca } & \multirow{2}{*}{ 31. 8. 2018.} & $30 \mathrm{~m}$ dubine & 7.4 & 7.3 & 86 \\
\hline & & & $50 \mathrm{~m}$ dubine & 2.9 & 2.6 & 73 \\
\hline \multirow{2}{*}{4.} & \multirow{2}{*}{$\begin{array}{l}\text { Špilja u } \\
\text { Śtirovači }\end{array}$} & \multirow{2}{*}{ 1. 9. 2018.} & lijevi kanal & 4.8 & 4.4 & 73 \\
\hline & & & ulazna dvorana & 4.0 & 3.8 & 78 \\
\hline 5. & $\begin{array}{l}\text { Sniježnica u } \\
\text { Medvjeđoj } \\
\text { dolini }\end{array}$ & 2. 9. 2018 . & $\begin{array}{c}\text { dvorana u } \\
\text { špiljskom dijelu }\end{array}$ & 9.8 & 8.4 & 78 \\
\hline
\end{tabular}

\section{Popis kopnenih organizama}

Popis sadrži taksonomski popis organizama s pripadajućom ekološkom klasifikacijom (pojmovi ekološke klasifikacije objašnjeni su u Tabl. 3) utvrđenim istraživanjima u 2018. godini iz objekata: Jama pod Budinom kosicom, Jama u kuku, Sniježnica u Medvjeđoj dolini, Špilja u Štirovači i Terca.

U popisu su navedeni sakupljeni primjerci iz sljedećih taksonomskih skupina: pauci (Araneae), jednakonožni rakovi (Isopoda), strige (Chilopoda), dvojenoge (Diplopoda), skokuni (Collembola) i kornjaši (Coleoptera). Uz znanstveno ime vrste navodi se prezime autora opisa vrste i pripadajuća godina opisa. Ako je prezime autora u zagradi, znači da je vrsta prvotno bila opisana pod drugim rodom. Detaljan popis svojti po lokalitetima nalazi se u Tabl. 4.

${ }^{2}$ T. ROŽMAN et al., 2015, 9-17. 
Tabl. 3. Ekološka klasifikacija špiljskih organizama korištena u ovom izvještaju s pripadajućim oznakama i objašnjenjima. ${ }^{3}$

\begin{tabular}{|c|c|c|}
\hline Oznaka & Klasifikacija & Objašnjenje \\
\hline Tb & Troglobiont & $\begin{array}{r}\text { Kopneni organizmi koji su prilagođeni za život u podzemlju i } \\
\text { jedino tamo obitavaju. }\end{array}$ \\
\hline Tf & Troglofil & $\begin{array}{r}\text { Kopneni organizmi koji mogu cijeli ili dio životnog ciklusa } \\
\text { provesti u podzemlju, ali se mogu naći i izvan podzemnih staništa. }\end{array}$ \\
\hline Tx & Trogloksen & $\begin{array}{r}\text { Kopneni organizmi koji slučajno zalaze u podzemna staništa te } \\
\text { nemaju nikakvih prilagodbi za život u podzemlju. }\end{array}$ \\
\hline
\end{tabular}

\section{Pauci (Araneae)}

Porodica: Agelenidae

1. Histopona egonpretneri Deeleman-Reinhold, $1983 \quad \mathrm{Tf}$

2. Tegenaria sp.

Porodica: Linyphiidae

3. Troglohyphantes sp. nov.

4. Gen. sp.

Porodica: Liocranidae

5. Sagana cf. rutilans Thorell, $1875 \quad$ Tx

Porodica: Tetragnathidae

6. Metellina merianae (Simon, 1880)

\section{Jednakonožni rakovi (Isopoda)}

Porodica: Trichoniscidae

7. Titanethes albus (C. Koch, 1841) Tb

8. Androniscus roseus cf. ocellatus (Kesselyak, 1930) Tf

\section{Strige (Chilopoda)}

Porodica: Lithobiidae

9. Eupolybothrus sp.

10. Lithobius sp.

${ }^{3}$ E. TRAJANO, 2012, 275-277. 


\section{Dvojenoge (Diplopoda)}

Red: Chordeumatida

Porodica: Attemsiidae

11. Attemsia likana Strasser, 1966

Porodica: Anthogonidae

12. Egonpretneria sp.

$\mathrm{Tb}$

13. Haasia sp.

Red: Polydesmida

Porodica: Polydesmidae

14. Brachydesmus inferus Latzel, 1884

$\mathrm{Tb}$

15. Brachydesmus subterraneus Heller, 1858

\section{Skokuni (Collembola)}

Porodica: Neanuridae

16. Neanuridae gen. sp.

Porodica: Onychiuridae

17. Onychiuroides sp.

Porodica: Tomoceridae

18. Tomocerus sp.

19. Tritomurus scutellatus Frauenfeld, $1854 \quad \mathrm{~Tb}$

Porodica: Entomobryidae

20. Lepidocyrtus sp.

21. Pseudosinella sp.

22. Entomobryidae gen. sp.

Porodica: Paronellidae

23. Troglopedetes sp.

\section{Kornjaši (Coleoptera)}

Porodica: Carabidae

24. Typhlotrechus bilimekii (Sturm, 1847) $\mathrm{Tb}$

Porodica: Cholevidae

25. Astagobius angustatus (Schmidt, 1852) $\mathrm{Tb}$

26. Redensekia $\mathrm{sp.} \quad \mathrm{Tb}$

27. Spelaeodromus pluto (Reitter, 1881) Tb 
Tabl. 4. Popis faune utvrđene u istraživanim speleološkim objektima. Prikupljeni materijal pohranjen je u Zbirci HBSD-a. AR - kratica za zbirku pauka; IT - kratica za zbirku kopnenih jednakonožnih rakova; DIP - kratica za zbirku dvojenoga; f - ženka; juv - juvenilna, spolno nerazvijena jedinka; m - mužjak; ad - adultna jedinka.

\begin{tabular}{|c|c|c|c|c|c|}
\hline $\begin{array}{c}\text { Ime } \\
\text { objekta }\end{array}$ & Skupina & Svojta & Kod & $\begin{array}{c}\text { Broj } \\
\text { primjeraka }\end{array}$ & Sakupljač, datum, odredio \\
\hline \multirow{19}{*}{ 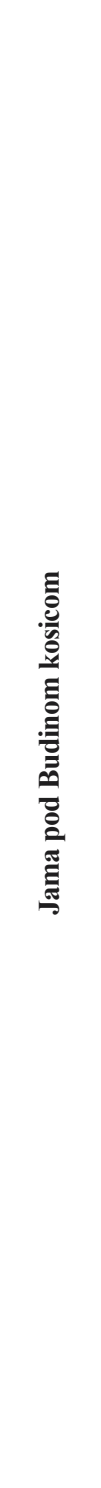 } & Araneae & Histopona sp. & AR5730 & 1 juv m & $\begin{array}{l}\text { leg. T. Rožman, 29.08.2018., } \\
\text { det. T. Rožman \& M. Pavlek }\end{array}$ \\
\hline & Araneae & $\begin{array}{l}\text { Linyphiidae Gen. } \\
\text { sp. }\end{array}$ & AR5731 & $1 \mathrm{~m}$ & $\begin{array}{l}\text { leg. T. Rožman, 29.08.2018., } \\
\text { det. T. Rožman \& M. Pavlek }\end{array}$ \\
\hline & Isopoda & Tithanethes albus & IT4290 & $1 \mathrm{fad}-\mathrm{juv}$ & $\begin{array}{l}\text { leg. P. Bregović, 29.08.2018., } \\
\text { det. J. Bedek }\end{array}$ \\
\hline & Isopoda & Tithanethes albus & IT4291 & $1 \mathrm{f}$ & $\begin{array}{l}\text { leg. B. Jalžić, 20.07.2017., det. } \\
\text { J. Bedek }\end{array}$ \\
\hline & Diplopoda & Egonpretneria sp. & DIP1202b & 1 juv & $\begin{array}{l}\text { leg. T. Rožman, 29.08.2018., } \\
\text { det. T. Dražina }\end{array}$ \\
\hline & Diplopoda & Egonpretneria sp. & & 2 & $\begin{array}{l}\text { leg. P. Kutleša, 29.08.2018., } \\
\text { det. T. Dražina }\end{array}$ \\
\hline & Diplopoda & $\begin{array}{l}\text { Brachydesmus } \\
\text { inferus }\end{array}$ & DIP1202a & $1 \mathrm{f}$ & $\begin{array}{l}\text { leg. T. Rožman, 29.08.2018., } \\
\text { det. T. Dražina }\end{array}$ \\
\hline & Diplopoda & $\begin{array}{l}\text { Brachydesmus } \\
\text { inferus }\end{array}$ & & 1 & $\begin{array}{l}\text { leg. A. Ćukušić, 29.08.2018., } \\
\text { det. T. Dražina }\end{array}$ \\
\hline & Diplopoda & $\begin{array}{l}\text { Brachydesmus } \\
\text { inferus }\end{array}$ & & 3 & $\begin{array}{l}\text { leg. P. Bregović, 29.08.2018., } \\
\text { det. T. Dražina }\end{array}$ \\
\hline & Diplopoda & $\begin{array}{l}\text { Brachydesmus } \\
\text { inferus }\end{array}$ & & 2 & $\begin{array}{l}\text { leg. T. Rožman, 29.08.2018., } \\
\text { det. T. Dražina }\end{array}$ \\
\hline & Diplopoda & Brachydesmus sp. & & 2 & $\begin{array}{l}\text { leg. H. Bilandžija, 29.08.2018., } \\
\text { det. T. Dražina }\end{array}$ \\
\hline & Collembola & Pseudosinella sp. & & 12 & $\begin{array}{l}\text { leg. H. Bilandžija, 29.08.2018., } \\
\text { det. M. Lukić }\end{array}$ \\
\hline & Collembola & Pseudosinella sp. & & 3 & $\begin{array}{l}\text { leg. T. Rožman, 29.08.2018., } \\
\text { det. M. Lukić }\end{array}$ \\
\hline & Collembola & Pseudosinella sp. & & 1 & $\begin{array}{l}\text { leg. A. Ćukušić, 29.08.2018., } \\
\text { det. M. Lukić }\end{array}$ \\
\hline & Collembola & Pseudosinella sp. & & 1 & $\begin{array}{l}\text { leg. P. Bregović, 29.08.2018., } \\
\text { det. M. Lukić }\end{array}$ \\
\hline & Collembola & Troglopedetes sp. & & 1 & $\begin{array}{l}\text { leg. A. Ćukušić, 29.08.2018., } \\
\text { det. M. Lukić }\end{array}$ \\
\hline & Coleoptera & $\begin{array}{l}\text { Spelaeodromus } \\
\text { pluto }\end{array}$ & & 2 & $\begin{array}{l}\text { leg. T. Rožman, 29.08.2018., } \\
\text { det. P. Bregović }\end{array}$ \\
\hline & Coleoptera & $\begin{array}{l}\text { Spelaeodromus } \\
\text { pluto }\end{array}$ & & 1 & $\begin{array}{l}\text { leg. P. Bregović, 29.08.2018., } \\
\text { det. P. Bregović }\end{array}$ \\
\hline & Coleoptera & $\begin{array}{l}\text { Typhlotrechus } \\
\text { bilimekii }\end{array}$ & & 1 & $\begin{array}{l}\text { leg. A. Ćukušić, 29.08.2018., } \\
\text { det. P. Bregović }\end{array}$ \\
\hline
\end{tabular}




\begin{tabular}{|c|c|c|c|c|c|}
\hline $\begin{array}{c}\text { Ime } \\
\text { objekta }\end{array}$ & Skupina & Svojta & Kod & $\begin{array}{c}\text { Broj } \\
\text { primjeraka }\end{array}$ & Sakupljač, datum, odredio \\
\hline \multirow{22}{*}{ 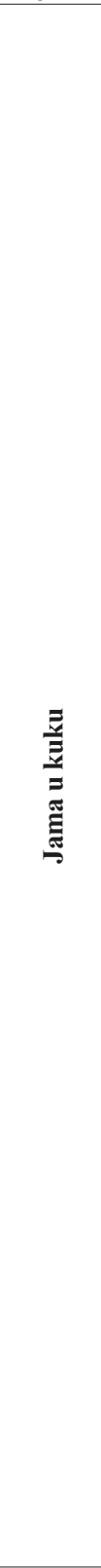 } & Araneae & $\begin{array}{l}\text { Histopona } \\
\text { egonpretneri }\end{array}$ & AR5751 & $1 \mathrm{f}$ & $\begin{array}{l}\text { leg. T. Rožman, 30.08.2018., } \\
\text { det. T. Rožman \& M. Pavlek }\end{array}$ \\
\hline & Araneae & $\begin{array}{l}\text { Linyphiidae Gen. } \\
\text { sp. }\end{array}$ & AR5748 & $2 \mathrm{f}, 1$ juv & $\begin{array}{l}\text { leg. P. Kutleša, 30.08.2018., } \\
\text { det. T. Rožman \& M. Pavlek }\end{array}$ \\
\hline & Araneae & $\begin{array}{l}\text { Linyphiidae Gen. } \\
\text { sp. }\end{array}$ & AR5749 & $1 \mathrm{~m}, 2$ juv & $\begin{array}{l}\text { leg. A. Ćukušić, 30.08.2018. } \\
\text { det. T. Rožman \& M. Pavlek }\end{array}$ \\
\hline & Araneae & $\begin{array}{l}\text { Linyphiidae Gen. } \\
\text { sp. }\end{array}$ & AR5750 & $6 \mathrm{f}, 2$ juv & $\begin{array}{l}\text { leg. T. Rožman, 30.08.2018., } \\
\text { det. T. Rožman \& M. Pavlek }\end{array}$ \\
\hline & Araneae & $\begin{array}{l}\text { Linyphiidae Gen. } \\
\text { sp. }\end{array}$ & AR5753 & $1 \mathrm{f}$ & $\begin{array}{l}\text { leg. T. Rožman, 30.08.2018., } \\
\text { det. T. Rožman \& M. Pavlek }\end{array}$ \\
\hline & Araneae & Sagana cf. rutilans & AR5754 & $1 \mathrm{f}$ & $\begin{array}{l}\text { leg. T. Rožman, 30.08.2018., } \\
\text { det. T. Rožman \& M. Pavlek }\end{array}$ \\
\hline & Isopoda & $\begin{array}{l}\text { Androniscus roseus } \\
\text { cf. ocellatus }\end{array}$ & IT4282 & $\begin{array}{l}4 \mathrm{~m}, 1 \mathrm{~m} \text { ad-juv, } \\
7 \mathrm{f}, 3 \text { f ad-juv, } \\
2 \text { juv }\end{array}$ & $\begin{array}{l}\text { leg. P. Kutleša, 30.08.2018., } \\
\text { det. J. Bedek }\end{array}$ \\
\hline & Isopoda & $\begin{array}{l}\text { Androniscus roseus } \\
\text { cf. ocellatus }\end{array}$ & IT4283 & $\begin{array}{l}1 \mathrm{~m}, 1 \mathrm{~m} \text { ad-juv, } \\
2 \mathrm{f}, 5 \mathrm{f} \text { ad-juv }\end{array}$ & $\begin{array}{l}\text { leg. P. Kutleša, 30.08.2018., } \\
\text { det. J. Bedek }\end{array}$ \\
\hline & Isopoda & $\begin{array}{l}\text { Androniscus roseus } \\
\text { cf. ocellatus }\end{array}$ & IT4284 & $1 \mathrm{f}$ & $\begin{array}{l}\text { leg. T. Rožman, 30.08.2018., } \\
\text { det. J. Bedek }\end{array}$ \\
\hline & Isopoda & $\begin{array}{l}\text { Androniscus roseus } \\
\text { cf. ocellatus }\end{array}$ & IT4285 & 1 juv & $\begin{array}{l}\text { leg. A. Ćukušić, 30.08.2018., } \\
\text { det. J. Bedek }\end{array}$ \\
\hline & Chilopoda & Lithobius sp. & & 1 juv & $\begin{array}{l}\text { leg. A. Ćukušić, 30.08.2018., } \\
\text { det. A. Komerički }\end{array}$ \\
\hline & Diplopoda & Brachydesmus sp. & & 1 & $\begin{array}{l}\text { leg. P. Kutleša, 30.08.2018., } \\
\text { det. T. Dražina }\end{array}$ \\
\hline & Diplopoda & Brachydesmus sp. & & 2 & $\begin{array}{l}\text { leg. A. Ćukušić, 30.08.2018., } \\
\text { det. T. Dražina }\end{array}$ \\
\hline & Collembola & Pseudosinella sp. & & 10 & $\begin{array}{l}\text { leg. P. Kutleša, 30.08.2018., } \\
\text { det. M. Lukić }\end{array}$ \\
\hline & Collembola & Pseudosinella sp. & & 8 & $\begin{array}{l}\text { leg. T. Rožman, 30.08.2018., } \\
\text { det. M. Lukić }\end{array}$ \\
\hline & Collembola & Onychiuroides sp. & & 1 & $\begin{array}{l}\text { leg. P. Kutleša, 30.08.2018., } \\
\text { det. M. Lukić }\end{array}$ \\
\hline & Collembola & Onychiuroides sp. & & 2 & $\begin{array}{l}\text { leg. T. Rožman, 30.08.2018., } \\
\text { det. M. Lukić }\end{array}$ \\
\hline & Collembola & Onychiuroides sp. & & 2 & $\begin{array}{l}\text { leg. A. Ćukušić, 30.08.2018., } \\
\text { det. M. Lukić }\end{array}$ \\
\hline & Collembola & Tomocerus sp. & & 12 & $\begin{array}{l}\text { leg. P. Kutleša, 30.08.2018., } \\
\text { det. M. Lukić }\end{array}$ \\
\hline & Collembola & Tomocerus sp. & & 1 & $\begin{array}{l}\text { leg. P. Kutleša, 30.08.2018., } \\
\text { det. M. Lukić }\end{array}$ \\
\hline & Collembola & $\begin{array}{l}\text { Tomocerus } \\
\text { scutellatus }\end{array}$ & & 1 & $\begin{array}{l}\text { leg. T. Rožman, 30.08.2018., } \\
\text { det. M. Lukić }\end{array}$ \\
\hline & Coleoptera & $\begin{array}{l}\text { Typhlotrechus } \\
\text { bilimekii }\end{array}$ & & 1 & $\begin{array}{l}\text { leg. T. Rožman, 30.08.2018., } \\
\text { det. P. Bregović }\end{array}$ \\
\hline
\end{tabular}




\begin{tabular}{|c|c|c|c|c|c|}
\hline $\begin{array}{c}\text { Ime } \\
\text { objekta }\end{array}$ & Skupina & Svojta & Kod & $\begin{array}{c}\text { Broj } \\
\text { primjeraka }\end{array}$ & Sakupljač, datum, odredio \\
\hline \multirow{17}{*}{ : } & Araneae & $\begin{array}{l}\text { Linyphiidae gen. } \\
\text { sp. }\end{array}$ & AR5732 & $1 \mathrm{f}$ & $\begin{array}{l}\text { leg. A. Ćukušić, 31.08.2018., } \\
\text { det. T. Rožman \& M. Pavlek }\end{array}$ \\
\hline & Araneae & $\begin{array}{l}\text { Linyphiidae gen. } \\
\text { sp. }\end{array}$ & AR5733 & 1 juv & $\begin{array}{l}\text { leg. H. Bilandžija, } \\
\text { 31.08.2018., det. T. Rožman } \\
\text { \& M. Pavlek }\end{array}$ \\
\hline & Isopoda & $\begin{array}{l}\text { Androniscus roseus } \\
\text { cf. ocellatus }\end{array}$ & IT4289 & $\begin{array}{l}2 \mathrm{~m}, 6 \mathrm{f}, 3 \mathrm{f} \\
\text { ad-juv }\end{array}$ & $\begin{array}{l}\text { leg. H. Bilandžija, } \\
\text { 31.08.2018., det. J. Bedek }\end{array}$ \\
\hline & Chilopoda & Lithobius sp. & & $1 \mathrm{~m}$ & $\begin{array}{l}\text { leg. T. Rožman, 31.08.2018., } \\
\text { det. A. Komerički }\end{array}$ \\
\hline & Chilopoda & Lithobius sp. & & $1 \mathrm{f}$ & $\begin{array}{l}\text { leg. H. Bilandžija, } \\
\text { 31.08.2018., det. A. } \\
\text { Komerički }\end{array}$ \\
\hline & Diplopoda & $\begin{array}{l}\text { Brachydesmus } \\
\text { subterraneus }\end{array}$ & & 3 & $\begin{array}{l}\text { leg. H. Bilandžija, } \\
\text { 31.08.2018., det. T. Dražina }\end{array}$ \\
\hline & Diplopoda & $\begin{array}{l}\text { Brachydesmus } \\
\text { subterraneus }\end{array}$ & & 1 & $\begin{array}{l}\text { leg. T. Rožman, 31.08.2018., } \\
\text { det. T. Dražina }\end{array}$ \\
\hline & Collembola & Neanuridae gen. sp. & & 3 & $\begin{array}{l}\text { leg. H. Bilandžija, } \\
\text { 31.08.2018., det. M. Lukić }\end{array}$ \\
\hline & Collembola & Lepidocyrtus sp. & & 1 & $\begin{array}{l}\text { leg. A. Ćukušić, 31.08.2018., } \\
\text { det. M. Lukić }\end{array}$ \\
\hline & Collembola & Pseudosinella sp. & & 1 & $\begin{array}{l}\text { leg. H. Bilandžija, } \\
\text { 31.08.2018., det. M. Lukić }\end{array}$ \\
\hline & Collembola & Pseudosinella sp. & & 2 & $\begin{array}{l}\text { leg. T. Rožman, 31.08.2018., } \\
\text { det. M. Lukić }\end{array}$ \\
\hline & Collembola & Tomocerus sp. & & 7 & $\begin{array}{l}\text { leg. H. Bilandžija, } \\
\text { 31.08.2018., det. M. Lukić }\end{array}$ \\
\hline & Collembola & Tomocerus sp. & & 8 & $\begin{array}{l}\text { leg. A. Ćukušić, 31.08.2018., } \\
\text { det. M. Lukić }\end{array}$ \\
\hline & Coleoptera & $\begin{array}{l}\text { Astagobius } \\
\text { angustatus }\end{array}$ & & 5 & $\begin{array}{l}\text { leg. T. Rožman, 31.08.2018., } \\
\text { det. P. Bregović }\end{array}$ \\
\hline & Coleoptera & $\begin{array}{l}\text { Spelaeodromus } \\
\text { pluto }\end{array}$ & & 2 & $\begin{array}{l}\text { leg. A. Ćukušić, 31.08.2018., } \\
\text { det. P. Bregović }\end{array}$ \\
\hline & Coleoptera & $\begin{array}{l}\text { Spelaeodromus } \\
\text { pluto }\end{array}$ & & 3 & $\begin{array}{l}\text { leg. T. Rožman, 31.08.2018., } \\
\text { det. P. Bregović }\end{array}$ \\
\hline & Coleoptera & $\begin{array}{l}\text { Spelaeodromus } \\
\text { pluto }\end{array}$ & & 1 & $\begin{array}{l}\text { leg. A. Ćukušić, 31.08.2018., } \\
\text { det. P. Bregović }\end{array}$ \\
\hline \multirow{4}{*}{ 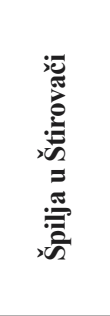 } & Araneae & $\begin{array}{l}\text { Troglohyphantes } \\
\text { sp. nov. }\end{array}$ & AR5736 & 2 juv, $2 \mathrm{f}, 1 \mathrm{~m}$ & $\begin{array}{l}\text { leg. T. Rožman, 01.09.2018., } \\
\text { det. T. Rožman \& M. Pavlek }\end{array}$ \\
\hline & Araneae & $\begin{array}{l}\text { Troglohyphantes } \\
\text { sp. nov. }\end{array}$ & AR5737 & $1 \mathrm{f}$ & $\begin{array}{l}\text { leg. M. Lukić, 31.07.2018., } \\
\text { det. T. Rožman \& M. Pavlek }\end{array}$ \\
\hline & Araneae & $\begin{array}{l}\text { Troglohyphantes } \\
\text { sp. nov. }\end{array}$ & AR5738 & 1 juv & $\begin{array}{l}\text { leg. H. Bilandžija, } \\
\text { 01.09.2018., det. T. Rožman } \\
\text { \& M. Pavlek }\end{array}$ \\
\hline & Chilopoda & Lithobius sp. & & $1 \mathrm{~m}$ & $\begin{array}{l}\text { leg. A. Ćukušić, 01.09.2018., } \\
\text { det. A. Komerički }\end{array}$ \\
\hline
\end{tabular}




\begin{tabular}{|c|c|c|c|c|c|}
\hline $\begin{array}{c}\text { Ime } \\
\text { objekta }\end{array}$ & Skupina & Svojta & Kod & $\begin{array}{c}\text { Broj } \\
\text { primjeraka }\end{array}$ & Sakupljač, datum, odredio \\
\hline \multirow{20}{*}{ 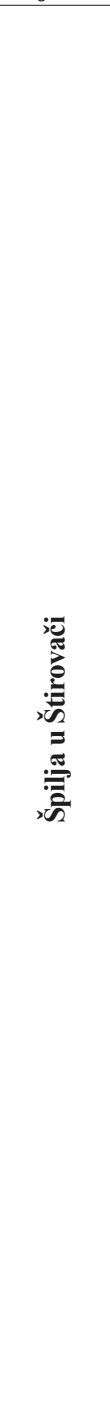 } & Chilopoda & Lithobius sp. & & $2 \mathrm{~m}$ & $\begin{array}{l}\text { leg. A. Ćukušić, 01.09.2018., } \\
\text { det. A. Komerički }\end{array}$ \\
\hline & Chilopoda & Lithobius sp. & & $3 \mathrm{~m}$ & $\begin{array}{l}\text { leg. M. Lukić, 31.07.2018., } \\
\text { det. A. Komerički }\end{array}$ \\
\hline & Diplopoda & Haasia sp. & DIP1204a & 1 juv & $\begin{array}{l}\text { leg. H. Bilandžija, } \\
\text { 01.09.2018., det. T. Dražina }\end{array}$ \\
\hline & Diplopoda & Egonpretneria sp. & DIP1201a & 1 juv & $\begin{array}{l}\text { leg. P. Bregović, 01.09.2018., } \\
\text { det. T. Dražina }\end{array}$ \\
\hline & Diplopoda & $\begin{array}{l}\text { Brachydesmus } \\
\text { subterraneus }\end{array}$ & DIP1204b & 1 juv & $\begin{array}{l}\text { leg. H. Bilandžija, } \\
\text { 01.09.2018., det. T. Dražina }\end{array}$ \\
\hline & Diplopoda & $\begin{array}{l}\text { Brachydesmus } \\
\text { subterraneus }\end{array}$ & & 1 & $\begin{array}{l}\text { leg. A. Ćukušić, 01.09.2018., } \\
\text { det. T. Dražina }\end{array}$ \\
\hline & Diplopoda & $\begin{array}{l}\text { Brachydesmus } \\
\text { subterraneus }\end{array}$ & DIP1203 & $1 \mathrm{~m}$ & $\begin{array}{l}\text { leg. A. Ćukušić, 01.09.2018., } \\
\text { det. T. Dražina }\end{array}$ \\
\hline & Diplopoda & $\begin{array}{l}\text { Brachydesmus } \\
\text { subterraneus }\end{array}$ & DIP1201b & $1 \mathrm{~m}, 2$ juv & $\begin{array}{l}\text { leg. P. Bregović, 01.09.2018., } \\
\text { det. T. Dražina }\end{array}$ \\
\hline & Diplopoda & $\begin{array}{l}\text { Brachydesmus } \\
\text { subterraneus }\end{array}$ & & 1 & $\begin{array}{l}\text { leg. A. Ćukušić, 01.09.2018., } \\
\text { det. T. Dražina }\end{array}$ \\
\hline & Diplopoda & $\begin{array}{l}\text { Brachydesmus } \\
\text { subterraneus }\end{array}$ & & 1 & $\begin{array}{l}\text { leg. P. Kutleša, 01.09.2018., } \\
\text { det. T. Dražina }\end{array}$ \\
\hline & Coleoptera & Redensekia sp. & & 1 & $\begin{array}{l}\text { leg. M. Lukić, 31.07.2018., } \\
\text { det. P. Bregović }\end{array}$ \\
\hline & Coleoptera & $\begin{array}{l}\text { Spelaeodromus } \\
\text { pluto }\end{array}$ & & 1 & $\begin{array}{l}\text { leg. A. Ćukušić, 01.09.2018., } \\
\text { det. P. Bregović }\end{array}$ \\
\hline & Coleoptera & $\begin{array}{l}\text { Spelaeodromus } \\
\text { pluto }\end{array}$ & & 2 & $\begin{array}{l}\text { leg. H. Bilandžija, } \\
\text { 01.09.2018., det. P. Bregović }\end{array}$ \\
\hline & Coleoptera & $\begin{array}{l}\text { Spelaeodromus } \\
\text { pluto }\end{array}$ & & 2 & $\begin{array}{l}\text { leg. P. Bregović, 01.09.2018., } \\
\text { det. P. Bregović }\end{array}$ \\
\hline & Coleoptera & $\begin{array}{l}\text { Spelaeodromus } \\
\text { pluto }\end{array}$ & & 1 & $\begin{array}{l}\text { leg. A. Ćukušić, 01.09.2018., } \\
\text { det. P. Bregović }\end{array}$ \\
\hline & Coleoptera & $\begin{array}{l}\text { Spelaeodromus } \\
\text { pluto }\end{array}$ & & 2 & $\begin{array}{l}\text { leg. P. Kutleša, 01.09.2018., } \\
\text { det. P. Bregović }\end{array}$ \\
\hline & Coleoptera & $\begin{array}{l}\text { Spelaeodromus } \\
\text { pluto }\end{array}$ & & 3 & $\begin{array}{l}\text { leg. M. Lukić, 31.07.2018., } \\
\text { det. P. Bregović }\end{array}$ \\
\hline & Coleoptera & $\begin{array}{l}\text { Spelaeodromus } \\
\text { pluto }\end{array}$ & & 1 & $\begin{array}{l}\text { leg. T. Rožman, 01.09.2018., } \\
\text { det. P. Bregović }\end{array}$ \\
\hline & Coleoptera & $\begin{array}{l}\text { Spelaeodromus } \\
\text { pluto }\end{array}$ & & 4 & $\begin{array}{l}\text { leg. M. Lukić, 31.07.2018., } \\
\text { det. P. Bregović }\end{array}$ \\
\hline & Coleoptera & $\begin{array}{l}\text { Spelaeodromus } \\
\text { pluto }\end{array}$ & & 2 & $\begin{array}{l}\text { leg. P. Kutleša, 01.09.2018., } \\
\text { det. P. Bregović }\end{array}$ \\
\hline & Araneae & Tegenaria sp. & AR5739 & $1 \mathrm{f}, 2$ juv $\mathrm{m}$ & $\begin{array}{l}\text { leg. T. Rožman, 02.09.2018., } \\
\text { det. T. Rožman \& M. Pavlek }\end{array}$ \\
\hline & Araneae & $\begin{array}{l}\text { Linyphiidae gen. } \\
\text { sp. }\end{array}$ & AR5240 & $1 \mathrm{f}, 1 \mathrm{~m}, 2$ juv & $\begin{array}{l}\text { leg. B. Jalžić, 21.07.2017., } \\
\text { det. T. Rožman \& M. Pavlek }\end{array}$ \\
\hline & Araneae & $\begin{array}{l}\text { Linyphiidae gen. } \\
\text { sp. }\end{array}$ & AR5741 & 3 juv $m, 1$ juv & $\begin{array}{l}\text { leg. T. Rožman, 02.09.2018., } \\
\text { det. T. Rožman \& M. Pavlek }\end{array}$ \\
\hline
\end{tabular}




\begin{tabular}{|c|c|c|c|c|c|}
\hline $\begin{array}{c}\text { Ime } \\
\text { objekta }\end{array}$ & Skupina & Svojta & Kod & $\begin{array}{c}\text { Broj } \\
\text { primjeraka }\end{array}$ & Sakupljač, datum, odredio \\
\hline \multirow{22}{*}{ 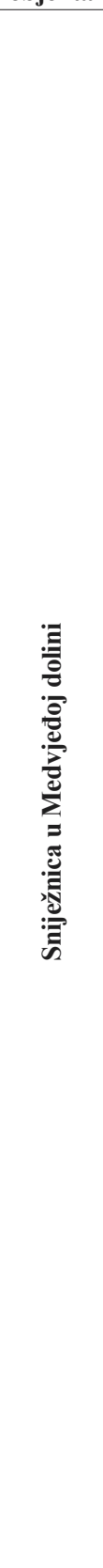 } & Araneae & $\begin{array}{l}\text { Linyphiidae gen. } \\
\text { sp. }\end{array}$ & AR5742 & 3 juv & $\begin{array}{l}\text { leg. T. Rožman, 02.09.2018., } \\
\text { det. T. Rožman \& M. Pavlek }\end{array}$ \\
\hline & Araneae & $\begin{array}{l}\text { Linyphiidae gen. } \\
\text { sp. }\end{array}$ & AR5743 & $1 \mathrm{f}$ & $\begin{array}{l}\text { leg. T. Rožman, 02.09.2018., } \\
\text { det. T. Rožman \& M. Pavlek }\end{array}$ \\
\hline & Araneae & $\begin{array}{l}\text { Linyphiidae gen. } \\
\text { sp. }\end{array}$ & AR5744 & $1 \mathrm{f}$ & $\begin{array}{l}\text { leg. T. Rožman, 02.09.2018., } \\
\text { det. T. Rožman \& M. Pavlek }\end{array}$ \\
\hline & Araneae & $\begin{array}{l}\text { Linyphiidae gen. } \\
\text { sp. }\end{array}$ & AR5746 & $1 \mathrm{~m}, 1 \mathrm{f}, 1$ juv & $\begin{array}{l}\text { leg. H. Bilandžija, } \\
\text { 02.09.2018., det. T. Rožman } \\
\text { \& M. Pavlek }\end{array}$ \\
\hline & Araneae & Metellina merianae & AR5740 & $1 \mathrm{f}$ & $\begin{array}{l}\text { leg. T. Rožman, 02.09.2018., } \\
\text { det. T. Rožman \& M. Pavlek }\end{array}$ \\
\hline & Isopoda & $\begin{array}{l}\text { Androniscus roseus } \\
\text { cf. ocellatus }\end{array}$ & IT4276 & $3 \mathrm{~m}, 1 \mathrm{f}, 2$ juv & $\begin{array}{l}\text { leg. B. Jalžić, 21.07.2017., } \\
\text { det. J. Bedek }\end{array}$ \\
\hline & Isopoda & $\begin{array}{l}\text { Androniscus roseus } \\
\text { cf. ocellatus }\end{array}$ & IT4277 & $\begin{array}{l}1 \mathrm{~m}, 1 \mathrm{~m} \\
\text { ad-juv, } 3 \mathrm{f}, 1 \mathrm{f} \\
\text { ad-juv, } 5 \text { juv }\end{array}$ & $\begin{array}{l}\text { leg. H. Bilandžija, } \\
\text { 02.09.2018., det. J. Bedek }\end{array}$ \\
\hline & Isopoda & $\begin{array}{l}\text { Androniscus roseus } \\
\text { cf. ocellatus }\end{array}$ & IT4278 & $\begin{array}{l}1 \mathrm{f}, 2 \mathrm{f} \text { ad-juv, } \\
3 \text { juv }\end{array}$ & $\begin{array}{l}\text { leg. A. Ćukušić, 02.09.2018., } \\
\text { det. J. Bedek }\end{array}$ \\
\hline & Isopoda & $\begin{array}{l}\text { Androniscus roseus } \\
\text { cf. ocellatus }\end{array}$ & IT4279 & $1 \mathrm{~m}, 1 \mathrm{f}, 4$ juv & $\begin{array}{l}\text { leg. P. Bregović, 02.09.2018., } \\
\text { det. J. Bedek }\end{array}$ \\
\hline & Isopoda & $\begin{array}{l}\text { Androniscus roseus } \\
\text { cf. ocellatus }\end{array}$ & IT4280 & $1 \mathrm{f}$ & $\begin{array}{l}\text { leg. P. Kutleša, 02.09.2018., } \\
\text { det. J. Bedek }\end{array}$ \\
\hline & Isopoda & $\begin{array}{l}\text { Androniscus roseus } \\
\text { cf. ocellatus }\end{array}$ & IT4281 & $1 \mathrm{f}$ & $\begin{array}{l}\text { leg. A. Ćukušić, 02.09.2018., } \\
\text { det. J. Bedek }\end{array}$ \\
\hline & Chilopoda & Eupolybothrus sp. & & $1 \mathrm{f}$ & $\begin{array}{l}\text { leg. A. Ćukušić, 02.09.2018., } \\
\text { det. A. Komerički }\end{array}$ \\
\hline & Chilopoda & Lithobius sp. & & $1 \mathrm{~m}$ & $\begin{array}{l}\text { leg. H. Bilandžija, } \\
\text { 02.09.2018., det. A. } \\
\text { Komerički }\end{array}$ \\
\hline & Diplopoda & Attemsia likana & DIP1200a & $1 \mathrm{~m}$ & $\begin{array}{l}\text { leg. H. Bilandžija, } \\
\text { 02.09.2018., det. T. Dražina }\end{array}$ \\
\hline & Diplopoda & $\begin{array}{l}\text { Brachydesmus } \\
\text { subterraneus }\end{array}$ & & 1 juv & $\begin{array}{l}\text { leg. A. Ćukušić, 02.09.2018., } \\
\text { det. T. Dražina }\end{array}$ \\
\hline & Diplopoda & $\begin{array}{l}\text { Brachydesmus } \\
\text { subterraneus }\end{array}$ & & 2 & $\begin{array}{l}\text { leg. P. Bregović, 02.09.2018., } \\
\text { det. T. Dražina }\end{array}$ \\
\hline & Diplopoda & $\begin{array}{l}\text { Brachydesmus } \\
\text { subterraneus }\end{array}$ & DIP1206 & $1 \mathrm{~m}$ & $\begin{array}{l}\text { leg. P. Kutleša, 02.09.2018., } \\
\text { det. T. Dražina }\end{array}$ \\
\hline & Diplopoda & $\begin{array}{l}\text { Brachydesmus } \\
\text { subterraneus }\end{array}$ & DIP1200b & 1 juv & $\begin{array}{l}\text { leg. H. Bilandžija, } \\
\text { 02.09.2018., det. T. Dražina }\end{array}$ \\
\hline & Diplopoda & $\begin{array}{l}\text { Brachydesmus } \\
\text { subterraneus }\end{array}$ & & 1 & $\begin{array}{l}\text { leg. P. Kutleša, 02.09.2018., } \\
\text { det. T. Dražina }\end{array}$ \\
\hline & Diplopoda & $\begin{array}{l}\text { Brachydesmus } \\
\text { subterraneus }\end{array}$ & & 1 & $\begin{array}{l}\text { leg. T. Rožman, 02.09.2018., } \\
\text { det. T. Dražina }\end{array}$ \\
\hline & Collembola & $\begin{array}{l}\text { Entomobryidae } \\
\text { gen. sp }\end{array}$ & & 1 & $\begin{array}{l}\text { leg. P. Bregović, 02.09.2018., } \\
\text { det. M. Lukić }\end{array}$ \\
\hline & Collembola & Lepidocyrtus sp. & & 2 & $\begin{array}{l}\text { leg. H. Bilandžija, } \\
\text { 02.09.2018., det. M. Lukić }\end{array}$ \\
\hline
\end{tabular}




\begin{tabular}{|c|c|c|c|c|c|}
\hline $\begin{array}{c}\text { Ime } \\
\text { objekta }\end{array}$ & Skupina & Svojta & Kod & $\begin{array}{c}\text { Broj } \\
\text { primjeraka }\end{array}$ & Sakupljač, datum, odredio \\
\hline & Collembola & Onychiuroides sp. & & 1 & $\begin{array}{l}\text { leg. P. Bregović, 02.09.2018., } \\
\text { det. M. Lukić }\end{array}$ \\
\hline & Collembola & Onychiuroides sp. & & 2 & $\begin{array}{l}\text { leg. A. Ćukušić, 02.09.2018., } \\
\text { det. M. Lukić }\end{array}$ \\
\hline & Collembola & Onychiuroides sp. & & 2 & $\begin{array}{l}\text { leg. P. Kutleša, 02.09.2018., } \\
\text { det. M. Lukić }\end{array}$ \\
\hline & Collembola & Pseudosinella sp. & & 1 & $\begin{array}{l}\text { leg. P. Bregović, 02.09.2018., } \\
\text { det. M. Lukić }\end{array}$ \\
\hline & Collembola & Pseudosinella sp. & & 2 & $\begin{array}{l}\text { leg. P. Kutleša, 02.09.2018., } \\
\text { det. M. Lukić }\end{array}$ \\
\hline & Collembola & Tomocerus sp. & & 3 & $\begin{array}{l}\text { leg. P. Bregović, 02.09.2018., } \\
\text { det. M. Lukić }\end{array}$ \\
\hline & Collembola & Tomocerus sp. & & 1 & $\begin{array}{l}\text { leg. H. Bilandžija, } \\
\text { 02.09.2018., det. M. Lukić }\end{array}$ \\
\hline
\end{tabular}

\section{Analiza sakupljene faune}

Ovim istraživanjima ukupno je zabilježeno 27 svojti iz sljedećih skupina: pauci (Araneae), jednakonožni rakovi (Isopoda), strige (Chilopoda), dvojenoge (Diplopoda), skokuni (Collembola) i kornjaši (Coleoptera). Najviše je zabilježeno skokuna ( 8 svojti), slijede pauci (6 svojti), dvojenoge ( 5 svojti), kornjaši (4 svojte), jednakonožni rakovi i strige (2 svojte). Najviše troglobionata, na život u podzemlju prilagođenih svojti, zabilježeno je kod skokuna i kornjaša (4 svojte), dvojenoge (3 svojte), pauci i jednakonožni rakovi (1 svojta).

Analiza sakupljene faune predstavljena je po taksonomskom redoslijedu i odnosi se na terenska istraživanja u 2018. godini iz slijedećih objekata: Jama pod Budinom kosicom, Jama u kuku, Sniježnica u Medvjeđoj dolini, Špilja u Štirovači i Terca.

$\mathrm{U}$ analizi faune naveden je pregled za svaku navedenu taksonomsku skupinu, istaknuti su endemi Parka, kao i nove vrste za znanost te je dana poveznica s dosadašnjom objavljenom biospeleološkom literaturom.

\section{Pauci (Araneae)}

Biospeleološkim istraživanjima u 2017. i 2018. godini na području Parka sakupljeno je 6 svojti pauka u 5 speleoloških objekata od čega 1 troglobiont, 3 troglofila, 1 trogloksen i 1 svojta kojoj nije moguće odrediti ekološku pripadnost. Sve su svojte, osim Linyphiidae Gen. sp., po prvi put zabilježene na području Parka. 


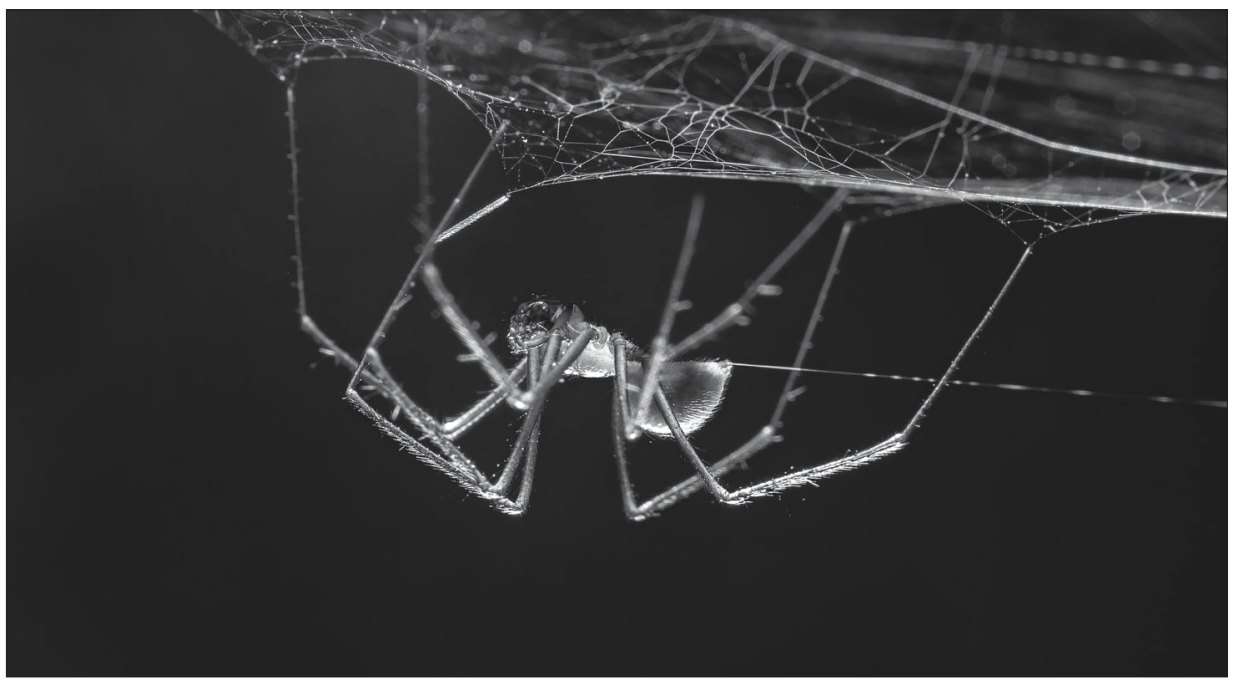

S1. 4. Nova vrsta pauka roda Troglohyphantes (foto: Tin Rožman)

Pauci iz porodice Agelenidae prepoznatljivi su po izrazito dugim predljivim bradavicama i velikim ljevkastim mrežama u čijem rubu čekaju plijen, a ovim istraživanjima zabilježene su dvije svojte. Vrsta Histopona egonpretneri zabilježena je i ranije na zapadnim padinama sjevernog Velebita (zbirka HBSD-a), ali nalaz u Jami u kuku prvi je nalaz unutar granica Parka. Područje sjevernog Velebita sjeverna je granica areala ove vrste dok južna seže do kanjona rijeke Zrmanje. Druga svojta iz ove porodice pripada rodu Tegenaria koji do sada nije zabilježen u Parku. Sakupljena je samo jedna ženka, u Sniježnici u Medvjeđoj dolini, koja podsjeća na vrstu $T$. decolorata. Ta vrsta je do sada poznata samo s otoka Krka. Opisan je mužjak dok ženka ove vrste za sada nije poznata te zbog toga ne možemo reći pripada li sakupljena ženka vrsti T. decolorata ili se možda radi o novoj vrsti za znanost. Za detaljnije analize potrebno je sakupiti mužjaka. Sakupljena jedinka pokazuje neke morfološke prilagodbe na podzemlje, npr. depigmentiranost, pa time zaključujemo da je vrsta vjerojatno troglofilnog karaktera.

Porodica Linyphiidae druga je najbrojnija porodica pauka na svijetu. Cijelu porodicu čine mali pauci koji grade nježne, horizontalne, plosnate i guste mreže po kojima se kreću s donje strane. Na području Parka ovom su prilikom zabilježene najmanje dvije svojte. Najznačajniji nalaz i jedini pravi špiljski i potpuno slijepi pauk zabilježen na ovom istraživanju je nova vrsta roda Troglohyphantes (Sl. 4) sakupljena u Špilji u Štirovači. To je ujedno prvi nalaz 
ove vrste za Park. Vrsta je od prije poznata iz obližnjeg objekta Ponor Štirovača te iz nekoliko objekata na području Kite Gavranuše i oko Donjeg Kosinja (zbirka HBSD-a). Sadašnji podaci o raširenosti govore da se radi o endemu Velebita i Like. Vrsta je troglobionta, potpuno slijepa i depigmentirana, a znanstveni opis tek slijedi. Određivanje drugih pronađenih jedinki ove porodice nažalost nije moguće zbog nedostatka kvalitetnih determinacijskih ključeva i nedovoljnoj istraženosti skupine na području Hrvatske.

Iz porodice Liocranidae pronađen je jedan odrasli primjerak ženke koji vjerojatno pripada vrsti Sagana cf. rutilans. Pronađeni primjerak pokazuje manje morfološke razlike u odnosu na vrstu Sagana rutilans pa na osnovi prikupljenog materijala nije moguće potvrditi radi li se o istoj vrsti.

U Sniježnici u Medvjeđoj dolini je pronađen primjerak vrste Metellina merianae iz porodice Tetragnathidae. Ista je, kao i neki drugi pripadnici te porodice, među najvećim paucima koji se mogu pronaći u speleološkim objektima. Iako izgledom i prvenstveno tamnom bojom ne podsjećaju na ostale špiljske pauke, ova vrsta je troglofil ${ }^{4}$ jer veći dio života provodi u špiljama ili sličnim tamnim i vlažnim staništima. Vrsta je rasprostranjena od Europe do Centralne Azije. ${ }^{5}$

\section{Jednakonožni rakovi (Isopoda)}

Od jednakonožnih rakova (Isopoda) su skupljene dvije svojte. U Jami pod Budinom kosicom sakupljeni su primjerci troglobiontne vrste Titanethes albus. Vrsta je endem sjevernih Dinarida, rasprostranjena je od Dinarskog dijela Italije, preko Slovenije, Hrvatske (Istra, Gorski kotar, Kordun, Žumberak, Lika, Velebit) do Sanskog Mosta u Bosni i Hercegovini. ${ }^{6}$

U većini speleoloških objekata (Jama u kuku, Sniježnica u Medvjeđoj dolini i Terca) sakupljena je troglofilna vrsta roda Androniscus. Radi se o vrsti Androniscus roseus cf. ocellatus (Sl. 5). Sakupljeni primjerci morfološki odgovaraju opisanoj podvrsti, međutim opis te podvrste je jako štur. Pretpostavlja se da je podvrsta, u originalu, skupljena na Velebitu. ${ }^{7}$ Determinaciju je sa sigurnošću moguće utvrditi jedino usporedbom s tipskim materijalom, vjerojatno pohranjenim u Berlinskom prirodoslovnom muzeju (Museum für Naturkunde Berlin). Ova podvrsta je endem Velebita, gdje dolazi u brojnim objektima (zbirka HBSDa).

${ }^{4}$ S. MAMMOLA et al., 2018, 301-316.

${ }^{5}$ W. NENTWIG et al., 2019.

${ }^{6}$ J. BEDEK et al., 2011, 237-354; H. SCHMALFUSS, 2003, 1-341; zbirka HBSD-a

${ }^{7}$ A. KESSELYAK, 1930, 50-66. 


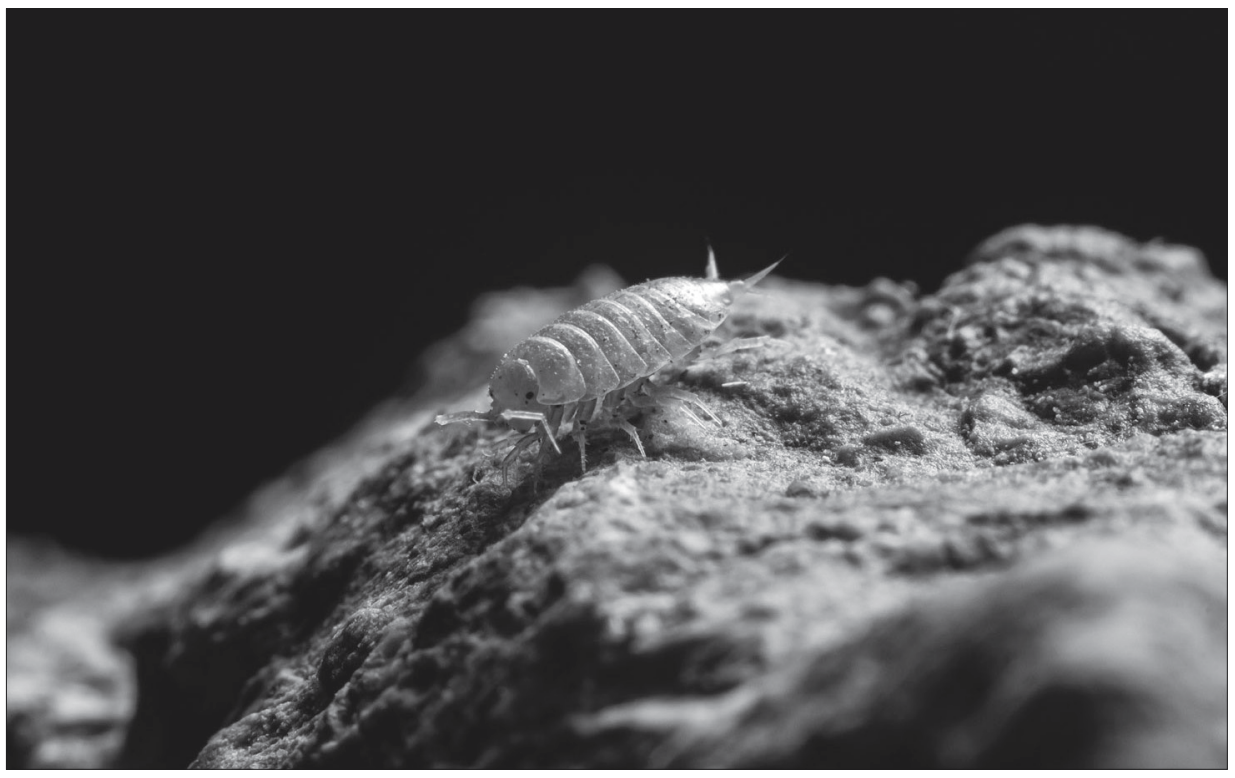

S1. 5. Jednakonožni rak Androniscus roseus cf. ocellatus u Jami u kuku (foto: Petra Bregović)

\section{Strige (Chilopoda)}

Tijekom srpnja i kolovoza 2018. godine, u četiri speleološka objekta Parka sakupljeno je osam primjeraka striga iz reda kamenjarki (Lithobiomorpha). Sedam ih pripada rodu Lithobius (S1. 6), dok je jedna odrasla ženka iz roda Eupolybothrus pronađena u Sniježnici u Medvjeđoj dolini. Da bi utvrdili o kojoj vrsti se radi, potrebno je sakupiti i determinirati mužjaka iz istog objekta, jer oni nose taksonomske značajke, tj. na njima se temelje opisi vrsta. U istoj je špilji pronađen i troglofilni primjerak roda Lithobius, što znači da unatoč fizičkoj sličnosti, imaju različite ekološke niše, npr. obitavaju u različitim staništima te se hrane različitim plijenom.

Pripadnici roda Lithobius vrlo su česti u podzemlju te su i vrstama najbrojniji rod striga u Hrvatskoj. ${ }^{8}$ Uglavnom je riječ o grabežljivcima koji žive u tlu. U Špilji u Štirovači pronađena su tri primjerka Lithobius sp. koji pripadaju istoj vrsti, no da bi utvrdili kojoj, potrebna je daljnja morfološka analiza. S obzirom na malu brojnost pronađenih primjeraka, za potpunije poznavanje bioraznolikosti striga Sjevernog Velebita potrebno je daljnje uzorkovanje.

\footnotetext{
${ }^{8}$ A. KOMERIČKI, 2009, 1-171.
} 


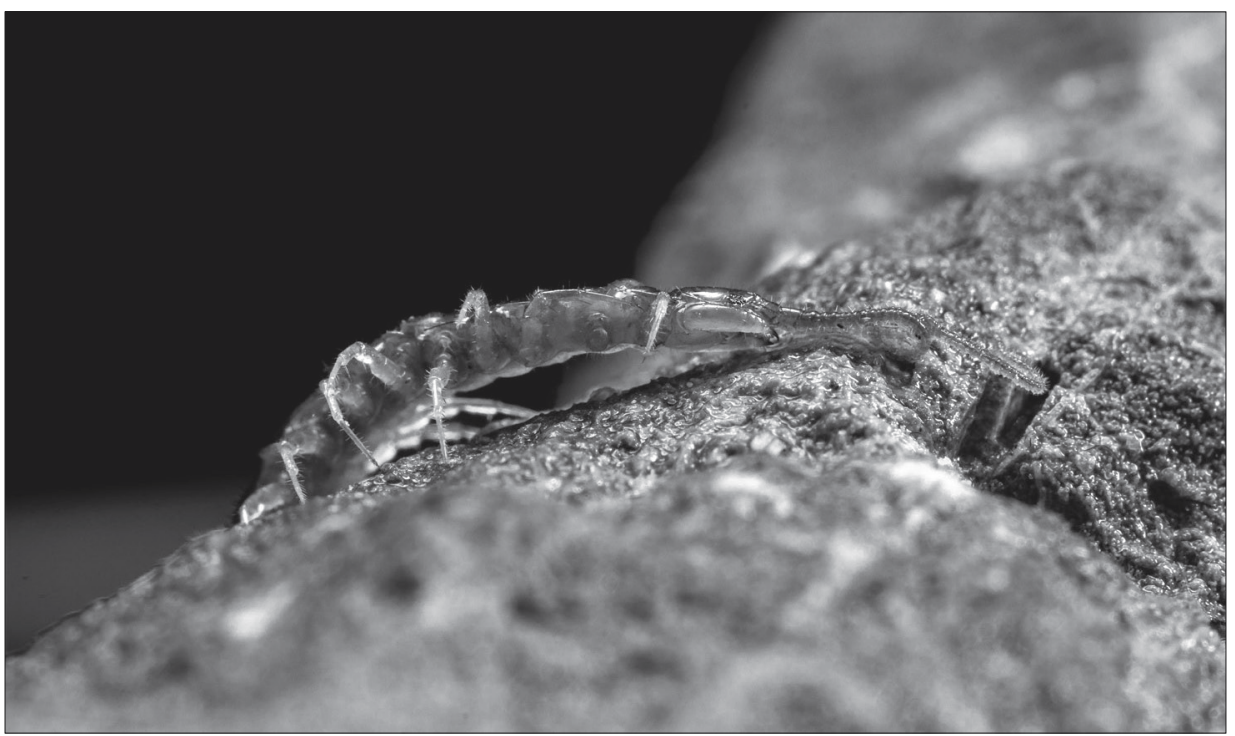

S1. 6. Striga roda Lithobius iz jame Terca (foto: Tin Rožman)

\section{Dvojenoge (Diplopoda)}

Od dvojenoga (Diplopoda) prikupljeno je pet različitih svojti, od kojih su tri troglobiontne, a dvije troglofilne. Iz reda kvrgastih dvojenoga (Chordeumatida) zabilježene su tri svojte: Egonpretneria sp., Haasia sp. i Attemsia likana.

Rod Egonpretneria je endemičan za područje Like i Velebita te su do sada poznate dvije vrste: E. brachychaeta Strasser, 1966, opisana i do sada zabilježena samo u Budinoj ledenici kraj Perušića i E. vudutschajldi Antić \& Dražina, 2015, zabilježena u nekoliko speleoloških objekata srednjeg i sjevernog Velebita. ${ }^{9}$ Ovim istraživanjem prikupljeni su samo juvenilni primjerci u Špilji u Štirovači i u Jami pod Budinom kosicom te ne možemo odrediti o kojoj se vrsti radi. Sličnu situaciju imamo i s jednom prikupljenom jedinkom roda Haasia u Špilji u Štirovači. Vjerojatno se radi o vrsti Haasia stenopodium, koja je zabilježena u brojnim speleološkim objektima na području NP Sjeverni Velebit. Areal ove vrste je relativno velik i proteže se od slovenskog dijela Dinarida, preko Učke i cijelog Velebita. ${ }^{10} \mathrm{U}$ budućim istraživanjima potrebno je sakupiti odrasle mužjake, kako bi potvrdili statuse vrsta.

${ }^{9}$ K. STRASSER, 1966, 379-398; D. ANTIĆ et al., 2015, 151-181; D. ANTIĆ et al., 2016, 1-23.

${ }^{10}$ D. ANTIĆ et al., 2015, 151-181; D. ANTIĆ et al., 2016, 1-23. 


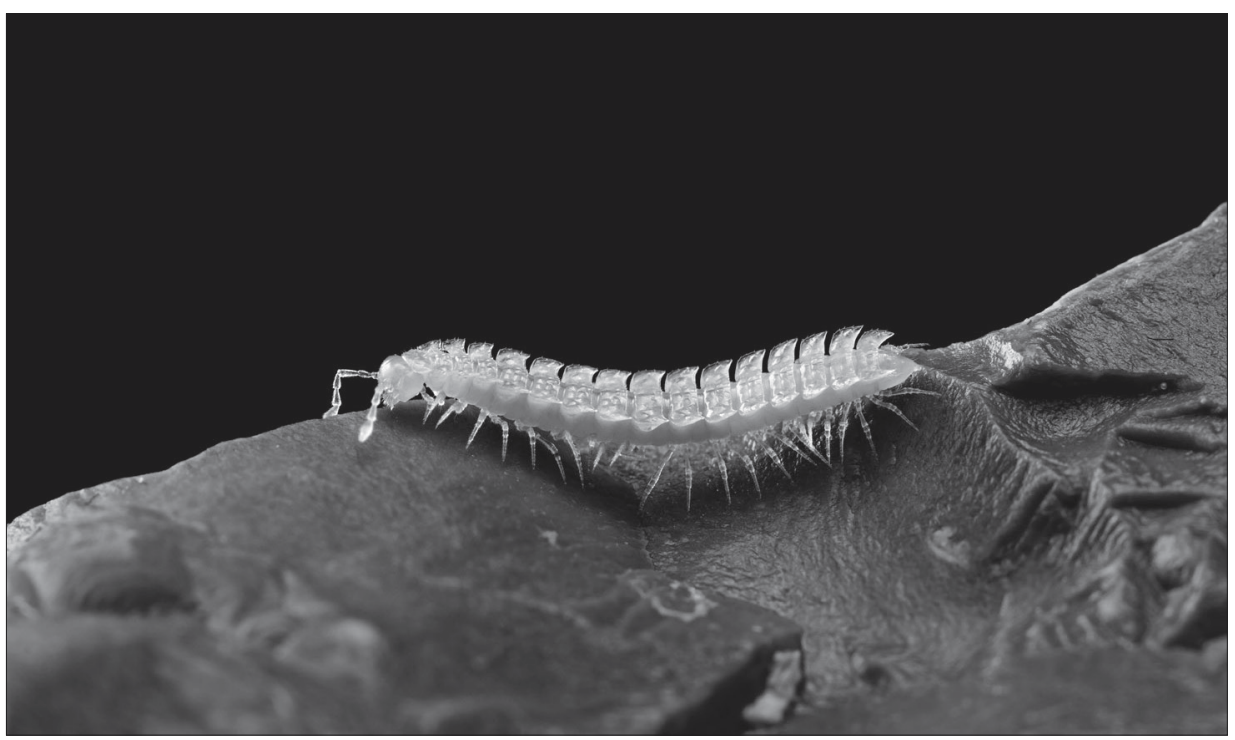

Sl. 7. Dvojenoga Brachydesmus inferus u Jami pod Budinom Kosicom (foto: Tin Rožman)

Faunistički je zanimljiv nalaz vrste Attemsia likana u Sniježnici u Medvjeđoj dolini. Do sada je $A$. likana zabilježena s područja Nacionalnog parka Plitvička jezera i Like ${ }^{11}$ te je ovo prvi nalaz ove vrste za Park.

Od vrpčastih dvojenoga (Polydesmida) zabilježene su dvije vrste roda Brachydesmus. B. subteranneus je troglofilna vrsta, jedna od najčešćih dvojenoga u podzemnim staništima Hrvatske. Ovim istraživanjima zabilježena je u Sniježnici u Medveđoj dolini, Špilji u Štirovači i Terci, a inače je rasprostranjena u središnjoj i jugoistočnoj Europi. Srodna vrsta je B. inferus (S1. 7), troglobiont, relativno velika dvojenoga prepoznatljiva po bočnim dorzalnim (leđnim) nastavcima na kolutićima koji su uzdignuti prema gore. Endem je Dinarida, a sada je sakupljena i u Jami pod Budinom kosicom.

\section{Skokuni (Collembola)}

Iz skupine skokuna (Collembola) utvrđeno je osam različitih svojti od kojih četiri predstavljaju troglobiontne svojte. S obzirom da se u većini speleoloških objekata istraživanih u sklopu ovog projekta do sada špiljska fauna nije sakupljala, podaci za skokune predstavljaju prve nalaze ovih svojti za te speleološke objekte.

${ }^{11}$ K. STRASSER, 1966, 379-398. 


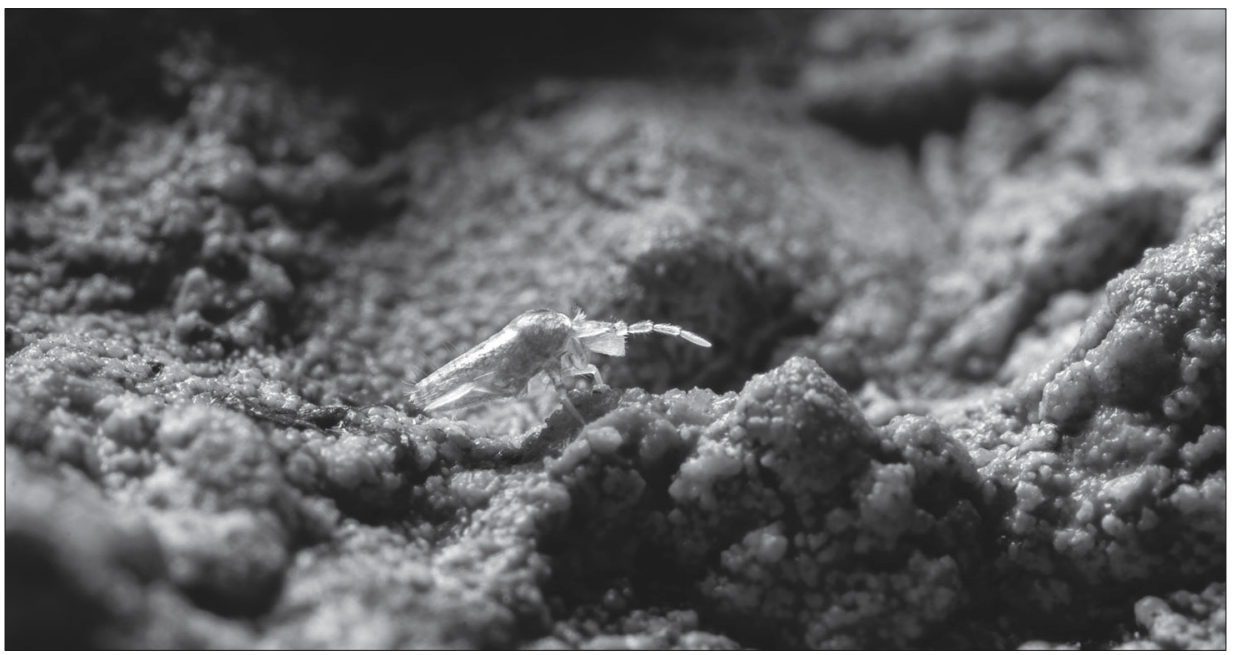

S1. 8. Skokun roda Pseudosinella iz Jame u kuku (foto: Tin Rožman)

Najčešća i najbrojnija troglobiontna svojta koja je utvrđena u svim istraživanim objektima pripada rodu Pseudosinella (S1. 8). U manjem broju primjeraka utvrđena je troglobiontna svojta iz roda Onychiuroides u Jami u kuku i Sniježnici u Medvjeđoj dolini, dok je samo jedan primjerak troglobiontne svojte iz roda Troglopedetes utvrđen u Jami pod Budinom Kosicom. Taksonomska obrada ovih uzoraka još je u tijeku te je potrebno sakupiti dodatni materijal ovih svojti sa područja Parka kao i komparativni materijal drugih vrsta ovih rodova opisanih iz speleoloških objekata na području Dinarida.

\section{Kornjaši (Coleoptera)}

Ovim istraživanjima zabilježene su četiri vrste troglobiontnih kornjaša. Vrsta Typhlotrechus bilimekii zabilježena je prije u Slovačkoj jami ${ }^{12}$, a ovim istraživanjima zabilježena je u Jami pod Budinom kosicom i Jami u kuku. Inače, vrsta je endem sjevernih Dinarida te dolazi na području Italije, Slovenije, Hrvatske i Bosne i Hercegovine. ${ }^{13}$

Vrsta Astagobius angustatus sada je zabilježena u jami Terca. Od prije je poznata iz mnogih objekta na području Parka. ${ }^{14}$ Vrsta je endem sjevernih

${ }^{12}$ D. BAKŠIĆ et al., 2000, 5-14; A. CASALE et al., 2004, 301-317.

${ }^{13}$ P. HLAVÁČ et al., 2017, 1-267.

${ }^{14}$ D. BAKŠIĆ et al., 2000, 5-14; A. CASALE et al., 2004, 301-317; J. BEDEK - R. OZIMEC, 2004, 6-7; T. ČUKOVIĆ et al., 2014, 13-15; B. JALŽIĆ, 1982, 15-20. 


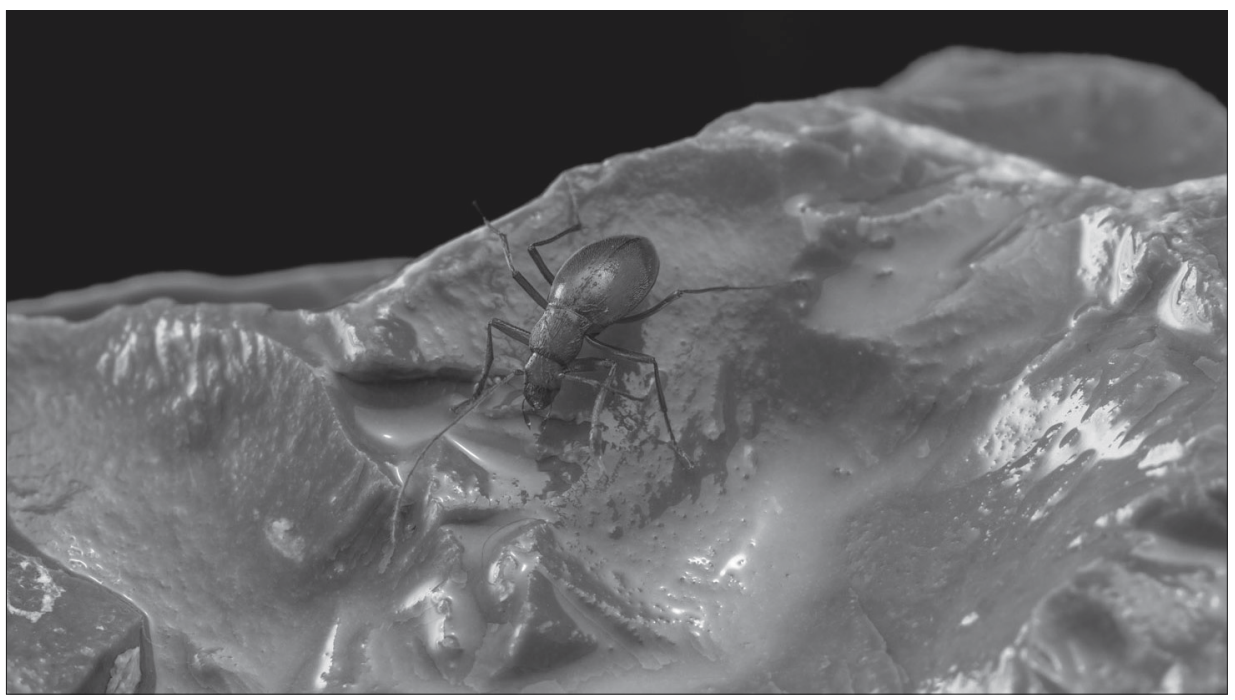

Sl. 9. Kornjaš Spelaeodromus pluto u Jami pod Budinom Kosicom (foto: Petra Bregović)

Dinarida, rasprostranjena je u Hrvatskoj i Sloveniji. ${ }^{15}$ Dolazi u objektima gdje je temperatura jako niska (blizu ledišta) i u kojima ima leda.

Vrsta iz roda Redensekia zabilježena je u Špilji u Štirovači, ali sakupljena je samo jedna ženka pa determinacija do vrste nije moguća. Vjerojatno se radi o vrsti Redensekia likana, opisanoj iz Donje Cerovačke špilje kod Gračaca ${ }^{16}$ i zasada jedinoj opisanoj vrsti toga roda, ali potrebno je sakupiti još materijala za potvrdu determinacije. Vrsta je od prije poznata na području Parka, samo iz dva objekta: Slovačka jama ${ }^{17}$ i Jama pod Zavižanom, ${ }^{18}$ te je ovo njezin treći nalaz za Park. Vrsta je endem Velebita, Like i Velike Kapele ${ }^{19}$.

Vrsta Spelaeodromus pluto (Sl. 9) zabilježena je u Jami pod Budinom kosicom, Terci i Špilji u Štirovači. Na području Parka zabilježena je u brojnim objektima. ${ }^{20}$ Vrsta je endem Velebita i Like. ${ }^{21}$

${ }^{15}$ P. HLAVÁČ et al., 2017, 1-267.

${ }^{16}$ Z. KARAMAN, 1953, 91-116.

${ }^{17}$ D. BAKŠIĆ et al., 2000, 5-14; A. CASALE et al., 2004, 301-317.

${ }^{18}$ E. PRETNER, 1973, 101- 239.

${ }^{19}$ P. HLAVÁČ et al., 2017, 1-267.

${ }^{20}$ J. BEDEK - R. OZIMEC, 2004, 6-7; J. BEDEK, 2005, 6; T. ČUKOVIĆ et al., 2014, 13-15; E. PRETNER, 1973, 101- 239.

${ }^{21}$ P. HLAVÁČ et al., 2017, 1-267. 


\section{Zaključak}

Provedbom projekta Biospeleološka istraživanja i inventarizacija faune u speleološkim objektima Nacionalnog parka Sjeverni Velebit ukupno je istraženo pet objekata u 2018. godini. Time je upotpunjen popis podzemne faune Parka jer su mnoge vrste po prvi put zabilježene u Parku, a barem jedna od njih predstavlja i novu vrstu za znanost. Istraživanjem dubokih jama i objekata manjih dimenzija na području cijelog Parka daje se naglasak na važnost sustavne inventarizacije podzemne faune speleoloških objekata kako bi se upotpunili podaci o ovoj iznimno vrijednoj fauni.

U sljedećem popisu ističemo najzanimljivije nalaze za Park (tj. endeme i nove vrste za znanost) utvrđene u ovom istraživanju (uz neke svojte ističe se važnost sakupljanja dodatnog materijala kao smjernice za daljnja istraživanja):

1. Histopona egonpretneri - prvi nalaz za Park, endem Velebita;

2. Troglohyphantes sp. nov. - prvi nalaz za Park, endem Velebita i Like, nova vrsta za znanost;

3. Egonpretneria sp. - prvi nalaz za Park, endem Velebita i Like, potrebno je sakupiti odraslog mužjaka za daljnju determinaciju iz Špilje u Štirovači i u Jami pod Budinom kosicom;

4. Attemsia likana - prvi nalaz za Park, endem Velebita i Like;

5. Redensekia sp. - treći nalaz za Park, endem Velebita, Like i Velike Kapele, potrebno je sakupiti mužjaka za daljnju determinaciju iz Špilje u Štirovači.

Ovim istraživanjem inventarizirana je podzemna fauna speleoloških objekata koji dosad nisu bili sustavno biospeleološki istraživani, što čini značajan doprinos poznavanju podzemne faune Parka. Podaci o vrstama koje su prvi put zabilježene za Park, kao i podaci o novim vrstama za znanost, ukazuju na nedovoljnu istraženost ovog područja i potrebu za daljnjim istraživanjima.

Dodatna su istraživanja svakako poželjna kako bi se upotpunili podaci i razriješila pitanja nastala ovim istraživanjem. Tek daljnjom višegodišnjom, sustavnom inventarizacijom podzemne faune, pogotovo neistraženih područja unutar Parka, dobila bi se potpunija slika bioraznolikosti podzemne faune Parka.

\section{Zahvala}

Istraživanje je financirala Javna ustanova "Nacionalni park Sjeverni Velebit". Ovim putem zahvaljujemo svim djelatnicima Parka na smještaju, pruženoj pomoći na terenu i suradnji. Zahvaljujemo i članovima Hrvatskog biospeleološkog društva koji su pomogli prilikom terenskih istraživanja: Helena Bilandžija, Anđela Ćukušić i Petra Kutleša. 


\section{Literatura}

Dragan Ž. ANTIĆ - Tvrko DRAŽINA - Tonči RAĐA - Vladimir T. TOMIĆ - Slobodan E. MAKAROV, Review of the family Anthogonidae (Diplopoda, Chordeumatida), with descriptions of three new species from the Balkan Peninsula, Zootaxa, 3948 (2), 2015, 151-181.

Dragan Ž. ANTIĆ - Tvrko DRAŽINA - Tonči RAĐA - Luka LUČIĆ - Slobodan E. MAKAROV, Taxonomic status of the family Biokoviellidae Mršić, 1992 (Diplopoda, Chordeumatida): reconsideration, with a description of one new species, European Journal of Taxonomy, 205, 2016, 1-23.

Darko BAKŠIĆ - Branko JALŽIĆ - Damir LACKOVIĆ, Slovačka jama na sjevernom Velebitu, Senjski Zbornik 27, Senj, 2000, 5-14.

Jana BEDEK - Roman OZIMEC, Biospeleološka istraživanja, u: Darko BAKŠIĆ, Jamski sustav Velebita, najveća podzemna vertikala na svijetu, Subterranea Croatica, 3, 2004, 6-7.

Jana BEDEK, Biospeleološka istraživanja, u: Darko BAKŠIĆ, Speleološka ekspedicija "Velebita 2005", Subterranea Croatica, 5, 2005, 6.

Jana BEDEK - Sanja GOTTSTEIN - Stefano TAITI, Catalogue and atlas of cave-dwelling terrestrial isopods (Crustacea: Oniscidea) from Croatia, Natura Croatica, 20, 2011, 237-354.

Achille CASALE - Pier Mauro GIACHINO - Branko JALŽIĆ, Three new species and one new genus of ultraspecialized cave dwelling Leptodirinae from Croatia (Coleoptera, Cholevidae), Natura Croatica, 13 (4), 2004, 301-317.

Tamara ČUKOVIĆ - Branko JALŽIĆ - Jana BEDEK - Ana KOMERIČKI - Helena BILANDŽIJA - Tvrtko DRAŽINA - Martina PAVLEK - Marko LUKIĆ - Kazimir MICULINIĆ - Roman OZIMEC, Biospeleološka istraživanja na ekspediciji Lukina jama-sifon 2013, Subterranea Croatica, 16, 2014, 13-15.

Peter HLAVÁČ - Michel PERREAU - David ČEPLÍK, The subterranean beetles of Balkan Peninsula, Czech University of Life Sciences, Faculty of Forestry and Wood Sciences, Department of Forest Protection and Entomology, Praha, 2017.

Branko JALŽIĆ, Über die Verbreitung der Höhlen-gattung Astagobius Reitter (Col., Catopidae) im Velebit Gebirge (Kroatien, Jugoslawien) mit der Beschreibung von A. angustatus vukusici, ssp. Nov, Acta entomologica Jugoslavica, 18 (1-2), 1982, $15-20$.

Zora KARAMAN, Über neue Coleopteren aus Jugoslavien, insebesonders aus Mazedonien, Acta Musei Macedonici Scientiarum Naturalium, 1/5, 1953, 91-116.

Adorján KESSELÝAK, Über Isopoden, Zoologischer Anzeiger, 91, 1930, 50-66.

Ana KOMERIČKI, Faunističke i biogeografske karakteristike striga Hrvatske s posebnim osvrtom na rod Eupolybothrus (Chilopoda: Lithobiidae) (diplomski rad), Prirodoslovno-matematički fakultet, Sveučilište u Zagrebu, 2009, 1-171.

Stefano MAMMOLA - Pedro CARDOSO - Carles RIBERA - Martina PAVLEK - Marco ISAIA, A synthesis on cave-dwelling spiders in Europe, J Zool Syst Evol Res., 56, 2018, 301-316.

Egon PRETNER, Koleopterološka fauna pećina i jama Hrvatske, Krš Jugoslavije, 8 (6), 1973, 101-239. 
Morana ROŽMAN - Neven BOČIĆ - Tin ROŽMAN - Tomisav DERDA, Međunarodna speleološka ekspedicija "Sjeverni Velebit - Mali lom 2014.", Subterranea Croatica, 13 (1), 2015, 9-17.

Helmut SCHMALFUSS, World catalog of terrestrial isopods (Isopoda: Oniscidea), Stuttgarter Beiträge zur Naturkunde, 2003, 654, 1-341.

Karl STRASSER, Neue Diplopoden aus Höhlen Jugoslawiens, Senckenbergiana biologica, 47 (5), 1966, 379-398.

Eleonora TRAJANO, Ecological classification of subterranean organisms, u: William WHITE - David CULVER (ur.), Encyclopedia of Caves, Academic Press, 2012, 275-277.

\section{Internetski izvori}

MINISTARSTVO ZAŠTITE OKOLIŠA I ENERGETIKE, Informacijski sustav zaštite prirode - Katastar speleoloških objekata Republike Hrvatske, Zagreb, 2019, URL: http://natura2000.dzzp.hr/speleo/ (2019-11-29)

Wolfgang NENTWIG - Teo BLICK - Daniel GLOOR - Ambros HANGGI - Christian KROPF, Spiders of Europe, version 09.2019, URL: https://araneae.nmbe.ch/ (201911-29)

\section{BIOSPELEOLOGICAL INVESTIGATIONS OF THE CAVES AND PITS OF THE NORTHERN VELEBIT NATIONAL PARK IN 2018}

\section{Summary}

Via the project 'Biospeleological investigations and inventory of the fauna in the speleological structures of the Northern Velebit National Park' in collaboration with the Northern Velebit National Park public institution and the Croatian Biospeleological Society, five speleological structures have been biospeleologically investigated: The pit below Budina kosica, the pit in Kuk, Sniježnica in Medvjeđa valley, the cave in Štirovača and Terca. In each structure the fauna was collected, the microclimatic parameters were measured and the entrance, underground spaces and fauna were photographed. Groups of spiders (Araneae), crustaceans (Isopoda), centipedes (Chilopoda), millipedes (Diplopoda), springtails (Collembola) and beetles (Coleoptera) were taxonomically processed in detail. In total, 27 taxa were recorded of which 13 are troglobion, i.e. species completely adapted to life underground. Four species were noted in the park for the first time, and one of them is new to science. The range of the measured air temperatures started from 2.9 to $9.8^{\circ} \mathrm{C}$ and this shows a great diversity of the habitats of the speleological structures of Northern Velebit, which is evident also by the number of recorded species. These results have complemented significantly to the list of the underground fauna of the park, expanded the knowledge of the recorded species and have highlighted the importance of the systematic inventorying of the underground fauna of speleological structures of all dimensions, small and large. Likewise, it has shown that the underground fauna of the Northern Velebit National Park is extremely interesting and worthy of preservation.

Keywords: biospeleological investigation, Northern Velebit, inventorying of fauna 